\title{
Patient safety culture shapes presenteeism and absenteeism: a cross-sectional study among Croatian healthcare workers
}

\author{
Hana Brborović and Ognjen Brborović \\ University of Zagreb School of Medicine, Andrija Štampar School of Public Health, Zagreb, Croatia
}

[Received in February 2017; Similarity Check in February 2017; Accepted in September 2017]

\begin{abstract}
Healthcare workers have high rates of injuries and illnesses at the workplace, and both their absence from work due to illness (absenteeism) or working ill (presenteeism) can compromise patient safety and the quality of health care delivered. Following this premise, we wanted to determine whether presenteeism and absenteeism were associated with patient safety culture (PSC) and in what way. Our sample consisted of 595 Croatian healthcare workers (150 physicians and 445 nurses) who answered the short-form WHO Health and Work Performance Questionnaire and the Hospital Survey on Patient Safety Culture. The results have confirmed the association with both presenteeism and absenteeism in several PSC dimensions, but not as we expected based on the premise from which we started. Opposite to our expectations, lower job performance (as a measure of presenteeism) was associated with higher PSC instead of lower PSC. Absenteeism, in turn, was associated with lower PSC, just as we expected. These findings suggest that it is the PSC that shapes presenteeist and absenteeist behaviour and not the other way around. High PSC leads to presenteeism, and low PSC to absenteeism. We also believe that the presenteeism questionnaires should be adjusted to health care and better define what lower performance means both quantitatively and qualitatively in a hospital setting.
\end{abstract}

KEY WORDS: nurses; physicians; work performance

Presenteeism and absenteeism are rather widespread and present a growing public health concern (1-3). Presenteeism is summarily defined as working ill instead of having taken leave (4) and entails lower performance at work due to health problems $(3,5,6)$. Absenteeism is defined as absence from work (7) due to valid (sick-leave) or less valid reasons (taking a day-off) (8). Both have a very similar negative effect on business, such as expenses and losses in work hours, production, and work morale $(9,10)$. Presenteeism is often a hidden cost, as workers are physically present, but their performance/productivity is poor $(3,11)$. A large study $(12)$ reported presenteeismrelated production losses of $72 \%$ compared with $28 \%$ of those caused by absenteeism. Other studies also reported higher costs of presenteeism than of absenteeism $(13,14)$.

Two longitudinal studies have indicated that presenteeism may increase the risk of future health disorders $(15,16)$, as it stands in the way of recovery $(3,17)$. In fact, presenteeism can lead to more sickness absence, as indicated by the positive correlation between the two in several studies $(4,18,19)$.

The extent of presenteeism is perhaps best illustrated by a Dutch study (20) reporting that $70 \%$ of the randomly

Correspondence to: Ognjen Brborović, MD, PhD, University of Zagreb, School of Medicine, Andrija Štampar School of Public Health, Department of Social Medicine and Organization of Health Care, Rockefellerova 4, 10000 Zagreb, Croatia, E-mail: obrborov@snz.hr selected participants had claimed to have worked sick at least once a year (20). With physicians, this prevalence soars to $90 \%(21-25)$.

In medical profession, presenteeism not only affects the quality of work $(3,11,26)$ but puts patients, colleagues, and visitors at the risk of contagion $(3,27)$. In other words, it compromises the very purpose of their work - patient safety. However, patient safety is difficult to measure due to the fear that "errors shall be punished" or the so-called cultural blame, as described in previous research $(28,29)$. Unwanted events or medical errors tend to be downplayed and underreported. Patient safety culture (PSC), on the other hand, is a more reliable measure of health workers' individual and group knowledge, beliefs, values, perception, competencies, behavioural patterns, and attitudes towards health and safety management in a healthcare organisation and it often serves as a proxy measure of patient safety (30-32).

So far, this issue has received modest attention (33-35), especially in Croatia (30), and the main objective of our study was to establish the association between presenteeism and absenteeism on the one hand and patient safety culture on the other. We also wanted to check again our previous negative findings (30) - no association between presenteeism and patient safety culture - on a much larger sample. 


\section{PARTICIPANTS AND METHODS}

Of the 863 invited participants 595 completed and returned the Hospital Survey on Patient Safety Culture (HSOPSC; response rate 68.95\%). Of these 595, 572 also answered the short version of the World Health Organization's Health and Work Performance Questionnaire (HPQ): 539 completed both the absenteeism and presenteeism section, 33 completed only the presenteeism section, and three completed only the absenteeism section.

The respondents consisted of 150 physicians and 445 nurses from two hospitals in Zagreb, Croatia. Their distribution by departments was as follows: internal medicine (42.35\%, 52 physicians and 200 nurses), surgery (18.82\%, 26 physicians and 86 nurses), anaesthesiology and intensive care (11.60\%, 29 physicians, 40 nurses), paediatrics (10.08\%, 14 physicians and 46 nurses), obstetrics ( $9.07 \%, 9$ physicians and 45 nurses), and psychiatry ( $8.08 \%, 20$ physicians and 28 nurses). All respondents gave their written consent.

\section{Health and Work Performance Questionnaire}

Presenteeism and absenteeism were assessed with the HPQ $(36,37)$, whose calibration studies show good concordance between measures of self-reported absenteeism and payroll records (Pearson's correlation 0.66 to 0.79 ) (36, 37). HPQ consists of seven items (of which one item consists of five sub-items). In this study, we followed the original scoring rules and used relative absenteeism and relative presenteeism data, which are recommended for regression analysis (38). Relative absenteeism is expressed as a percentage of expected hours. Negative scores mean that a person works overtime, while the score of +1 means that a person is always absent (38). Values equal to or higher than 0.1 were used as the cut-off score for absenteeism.

Relative presenteeism is a ratio of self-rated job performance and the rated performance of the colleagues at the same or similar job. To obtain this ratio the participants are asked to rate the usual performance of their colleagues at the same or similar jobs on a scale from 0 to 10 , where 0 is the poorest and 10 top performance. Then they are asked to rate their own job performance over the past 28 work days. The 0.25 ratio is the worst relative performance, and 2.0 is the best performance. Presenteeism included the ratios from 0.20 to $0.80(20 \%-80 \%$ of the colleague's usual performance) (38).

\section{Hospital Survey on Patient Safety Culture (HSOPSC)}

HSOPSC is designed to measure 12 dimensions of patient safety culture (10) by rating agreement ("Strongly disagree" to "Strongly agree") or frequency ("Never" to "Always") for 42 items on a 5-point Likert scale. We used the Croatian version of the HSOPSC, which showed acceptable reliability scores and a good fit to the original US questionnaire $(30,31)$.

\section{Procedure}

Both questionnaires were distributed in unmarked envelopes along with a consent form at morning staff and weekly educational meetings. The respondent returned the completed questionnaires and consent forms in separate sealed and unmarked envelopes by placing them in a box for each department. Department head nurses would then collect the boxes and returned them to the main investigator.

The study was approved by the ethics committees of the Zagreb University School of Medicine (because the first author was a postgraduate student at the time) and of the two participating hospitals.

\section{Statistical analysis}

Demographic data (such as gender, age, years of working experience, number of working hours, direct interaction or contact with patients) showed statistically significant multicollinearity and were therefore omitted from linear regression analysis.

To calculate composite scores we had to reverse-code the negatively worded items of the HSOPSC. The Kolmogorov-Smirnov test showed non-normal distribution of the data $(\mathrm{p}>0.05)$.

Linear regression was used to assess whether the twelve PSC dimensions were associated with presenteeism or absenteeism. In the first step, the data were adjusted for hospitals and departments. Presenteeism or absenteeism were used as predictors separately, resulting in 24 linear regression analyses.

All statistics was run on the SAS version 9.1.3 (SAS Institute Inc., SAS Campus Drive, Cary, NC, USA). Statistical significance was set at the p-value of $<0.05$.

\section{RESULTS AND DISCUSSION}

\section{Presenteeism and absenteeism}

Thirty-nine of $572(6.82 \%)$ respondents reported lower job performance, which translates to presenteeism.

Absenteeism (score $\geq 0.1$ ) was established for 90 of 542 $(16.60 \%)$ respondents and the mean loss of hours was almost eight hours in the previous week. Most respondents worked more work hours than expected.

\section{Patient safety culture}

Overall PSC was high (9 dimensions had values $\geq 3$ ). The exception are the dimensions of staffing and nonpunitive response to error in both hospitals, and hospital management support for patient safety in one hospital.

\section{Associations between presenteeism/absenteeism and PSC}

Table 1 shows the relations between relative presenteeism and relative absenteeism with PSC. Presenteeism had a significant positive association with PSC in four dimensions: 
Table 1 Associations between patient safety culture dimensions and presenteeism or absenteeism

\begin{tabular}{|c|c|c|c|c|c|c|c|}
\hline & & \multicolumn{3}{|c|}{ PRESENTEEISM } & \multicolumn{3}{|c|}{ ABSENTEEISM } \\
\hline & & B & $\mathbf{p}$ & $\mathbf{R 2}$ & B & $\mathbf{p}$ & $\mathbf{R}^{2}$ \\
\hline D1 & Staffing [1] & 0.018 & 0.659 & 0.044 & 0.195 & 0.001 & 0.042 \\
\hline D2 & Non-punitive response to error [2] & -0.053 & 0.169 & 0.18 & 0.077 & 0.05 & 0.179 \\
\hline D3 & $\begin{array}{c}\text { Organisational learning - continuous } \\
\text { improvement }\end{array}$ & -0.076 & 0.069 & 0.009 & -0.011 & 0.793 & 0.006 \\
\hline D4 & Feedback and communication about error & 0.019 & 0.658 & 0.001 & 0.054 & 0.211 & 0.004 \\
\hline D5 & Frequency of event reporting & -0.024 & 0.575 & 0.001 & -0.075 & 0.084 & 0.006 \\
\hline D6 & Communication openness [3] & -0.095 & 0.024 & 0.011 & 0.017 & 0.699 & 0.003 \\
\hline D7 & Teamwork across hospital units [4] & -0.152 & 0.001 & 0.041 & 0.069 & 0.106 & 0.016 \\
\hline D8 & Teamwork within hospital units & -0.049 & 0.246 & 0.006 & -0.026 & 0.547 & 0.003 \\
\hline D9 & $\begin{array}{l}\text { Supervisor/manager expectations and actions } \\
\text { promoting safety }\end{array}$ & -0.072 & 0.09 & 0.005 & 0.023 & 0.603 & 0.001 \\
\hline D10 & $\begin{array}{l}\text { Hospital management support for patient } \\
\text { safety }\end{array}$ & -0.001 & 0.975 & 0.09 & 0.003 & 0.944 & 0.08 \\
\hline D11 & Handoffs and transitions [5] & -0.083 & 0.046 & 0.019 & -0.015 & 0.727 & 0.011 \\
\hline D12 & Overall perceptions of safety [6] & -0.094 & 0.025 & 0.011 & 0.02 & 0.646 & 0.002 \\
\hline
\end{tabular}

communication openness, teamwork across hospital units, handoffs and transitions, and overall perceptions of safety. These results are contrary to our premise that high presenteeism (as a measure of low performance at work) should entail low PSC (as an indirect measure of patient safety).

Absenteeism also had a significant association with two PSC dimensions: staffing and non-punitive response to error. Unlike presenteeism, these results confirmed our expectations that higher absenteeism should be associated with lower PSC. Considering the opposite associations of presenteeism and absenteeism with PSC, we have come to the only interpretation possible that it is PSC that shapes presenteeist and absenteeist behaviour and not the other way around. High PSC leads to presenteeism, and low PSC to absenteeism. People with high patient safety culture (set of values they uphold) tend to appear at work even if they judge their performance lower than usual or in respect to others, while those with low patient safety culture tend to skip work. Another implication of our findings is that PSC is not a reliable measure of patient safety when it comes to presenteeism, as it would not correlate positively with poor performance at work or working ill if it were.

\section{Strengths and limitations}

The questionnaires we used are self-reported, which might entail some limitations. Bodur and Filiz (39) suggest that respondents lose interest and tend to inaccurately answer long self-reported questionnaires. Furthermore, even though the research was anonymous, social desirability bias cannot be excluded. Another limitation may arise from sample bias, as the two hospitals were not selected at random but for convenience.
Even so, this study provides important information on the use of HPQ and HSOPSC. First, the HPQ questionnaire does not describe what exactly low job performance is in the context of health care. It does not distinguish between quantitative (how many procedures were done) or qualitative evaluation (cordiality, safety). Johns $(40,41)$ suggested that self-reported presenteeism questionnaires evaluating productivity loss on a scale may be more prone to perceptual distortion than stating the number of days being absent, as the respondents are inclined to underreport poor performance. Instead, he suggested using open-ended questionnaires.

We strongly recommend that the existing definition of presenteeism and work performance be expanded and specifically adjusted to health care. Future research should aim at developing a short, reliable, and comprehensive tool that would measure all aspects of presenteeism (low job performance, sickness presenteeism).

\section{CONCLUSIONS}

Our results have demonstrated that patient safety culture shapes absenteeism/presenteeism. People with higher PSC are more likely to be presenteeists; people with lower PSC are more likely to be absenteeists.

While absenteeism is well defined in quantitative manner, future research should be aimed at redefining presenteeism in terms of job performance, specifically for healthcare settings. There is a clear unmet need for a more refined questionnaire that is better adjusted to the hospital setting, and that could better define what lower work performance means in quantitative and qualitative spectre. 


\section{Acknowledgments}

This study was part of the project no. 108-1080316-0300 "Health at the workplace and healthy working environment", funded by the Croatian Ministry of Science, Education and Sports. We sincerely thank Mr Dado Čakalo for his useful advice and valuable time.

\section{REFERENCES}

1. Janssens H, Clays E, de Clercq B, de Bacquer D, Casini A, Kittel F, Braeckman L. Association between psychosocial characteristics of work and presenteeism: A cross-sectional study. Int J Occup Med Environ Health 2016;29:331-44. doi: 10.13075/ijomeh.1896.00588

2. Widera E, Chang A, Chen HL. Presenteeism: A Public Health Hazard. J Gen Intern Med 2010;25:1244-47. doi: 10.1007/ s11606-010-1422-x

3. d'Errico A, Ardito C, Leombruni R. Work organization, exposure to workplace hazards and sickness presenteeism in the European employed population. Am J Ind Med 2016;59:57-72. doi: 10.1002/ajim.22522

4. Aronsson G, Gustafsson K, Dallner M. Sick but yet at work. An empirical study of sickness presenteeism. J Epidemiol Community Health 2000;54:502-9. doi: 10.1136/ jech.54.7.502

5. Lerner D, Amick B.I., Malspeis S, Rogers W. A national survey of health-related work limitations among employed persons in the United States. J Disab Rehab Res 2000;23:22532. doi: 10.1080/096382800296791

6. SchultzAB, Edington DW. Employee health and presenteeism: a systematic review. J Occup Rehabil 2007;17:547-79. doi: 10.1007/s10926-007-9096-x

7. Davey MM, Cummings G, Newburn-Cook CV, Lo EA Predictors of nurse absenteeism in hospitals: a systematic review. J Nurs Manag 2009;17:312-30. doi: 10.1111/j.1365-2834.2008.00958.x

8. Ferreira RC, Griep RH, de Jesus Mendes da Fonseca M. A multifactorial approach to sickness absenteeism among nursing staff. Rev Saude Publica 2012;16:259-68. doi: 10.1590/S0034-89102012005000018

9. Levin-Epstein J. Presenteeism and paid sick days [displayed 8 September 2017]. Available at http://www.clasp.org/admin/ site/publications/files/0212.pdf

10. Segal RM. Labor Relations. Chapter 14. Article 18. In: Annual Survey of Massachusetts Law. Boston: College Law School; 1955.

11. Hemp P. Presenteeism: at work-but out of it. Harv Bus Rev 2004;82:49-58, 155. PMID: 15559575

12. Stewart WF, Ricci JA, Chee E, Morganstein D, Lipton R. Lost productive time and cost due to common pain conditions in the US workforce. JAMA 2003;290:2443-54. doi: 10.1001/ jama.290.18.2443

13. Ammendolia C, Côté $\mathrm{P}$, Cancelliere C, Cassidy JD, Hartvigsen J, Boyle E, Soklaridis S, Stern P, Amick III B. Healthy and productive workers: using intervention mapping to design a workplace health promotion and wellness program to improve presenteeism. BMC Public Health 2016;25:1190. doi: 10.1186/s12889-016-3843-x

14. Goetzel RZ, Long SR, Ozminkowski RJ, Hawkins K, Wang $\mathrm{S}$, Lynch W. Health, absence, disability, and presenteeism cost estimates of certain physical and mental health conditions affecting U.S. employers. J Occup Environ Med 2004;46:398-412. doi: 10.1097/01.jom.0000121151.40413. bd

15. Bergstrom G, Bodin L, Hagberg J, Lindh T, Aronsson G, Josephson M. Does sickness presenteeism have an impact on future general health? Int Arch Occup Environ Health 2009;82:1179-90. doi: 10.1007/s00420-009-0433-6

16. Kivimäki M, Head J, Ferrie JE, Hemingway H, Shipley MJ, Vahtera J, Marmot MG. Working while ill as a risk factor for serious coronary events: the Whitehall II study. Am J Public Health 2005;95:98-102. doi: 10.2105/AJPH.2003.035873

17. Aronsson G, Gustafsson K. Sickness presenteeism: prevalence, attendance-pressure factors, and an outline of a model for research. J Occup Environ Med 2005;47:958-66. doi: 10.1097/01.jom.0000177219.75677.17

18. Caverley N, Cunningham JB, MacGregor JN. Sickness presenteeism, sickness absenteeism and health following restructuring in a public service organization. J Manag Stud 2007;44:304-19. doi: 10.1111/j.1467-6486.2007.00690.x

19. Elstad JI, Vabo M. Job stress, sickness absence and sickness presenteeism in Nordic elderly care. Scand J Public Health 2008;36:467-74. doi: 10.1177/1403494808089557

20. Hansen CD, Andersen JH. Going ill to work - What personal circumstances, attitudes and work-related factors are associated with sickness presenteeism? Soc Sci Med 2008;67:956-64. doi: 10.1016/j.socscimed.2008.05.02

21. Jena AB, Baldwin DC Jr, Daugherty SR, Meltzer DO, Arora VM. Presenteeism among resident physicians. JAMA 2010;304:1166-8. doi: 10.1001/jama.2010.1315.

22. Baldwin PJ, Dodd M, Wrate RM. Young doctors' health - II. Health and health behaviour. Soc Sci Med 1997;45:41-4. doi: 10.1016/S0277-9536(96)00307-3

23. Gudgeon P, Wells DA, Baelocher MO, Detsky AS. Do you come to work with a respiratory tract infection? Occup Environ Med 2009;66:424. doi: 10.1136/oem.2008.04392

24. Gustafsson Senden M, Løvseth LT, Schenck-Gustafsson K., Fridner A. What makes physicians go to work while sick: a comparative study of sickness presenteeism in four European countries (HOUPE). Swiss Med Wkly 2013;143. doi: 10.4414/smw.2013.13840

25. Rosvold EO, Bjertness E. Physicians who do not take sick leave: hazardous heroes? Scand J Public Health 2001;29:715. PMID: 11355720

26. Cicolini G, Della Pelle C, Cerratti F, Franza M, Flacco ME. Validation of the Italian version of the Stanford Presenteeism Scale in nurses. J Nurs Manag 2016;24:598-604. doi: 10.1111/jonm. 12362

27. Middaugh DJ. Presenteeism: sick and tired at work. Dermatol Nurs 2007;15:103-5. PMID: 1670025

28. Halbesleben JR, Wakefield BJ, Wakefield DS, Cooper LB. Nurse burnout and patient safety outcomes: nurse safety perception versus reporting behavior. West J Nurs Res 2008;30:560-77. doi: 10.1177/0193945907311322

29. Edmondson AC. Learning from mistakes is easier said than done: group and organizational influences on the detection and correction of human error. J Appl Behav Sci 2004;40:6690. doi: 10.1177/0021886396321001

30. Brborović H, Brborović O, Brumen V, Pavleković G, Mustajbegović J. Are nurse presenteeism and patient safety culture associated: a cross-sectional study. Arh Hig Rada 
Toksikol 2014;65:149-56. doi: 10.2478/10004-1254-652014-2462

31. Brborović H, Šklebar I, Brborović O, Brumen V, Mustajbegović J. Development of a Croatian version of the US Hospital Survey on Patient Safety Culture questionnaire: dimensionality and psychometric properties. Postgrad Med J 2014;90:125-32. doi: 10.1136/postgradmedj-2013-131814

32. Nieva VF, Sorra J. Safety culture assessment: a tool for improving patient safety in healthcare organizations. Qual Saf Health Care 2003;12(Suppl 2):ii17-23. doi: 10.1136/ qhc.12.suppl_2.ii17

33. Baptista PC, Pustiglione M, Almeida MC, Felli VE, Garzin AC, Melleiro MM. Nursing workers health and patient safety: the look of nurse managers. Rev Esc Enferm USP. 2015;49(2). doi: 10.1590/S0080-623420150000800017.

34. de Magalhães AM, Dall’Agnol CM, Marck PB. Nursing workload and patient safety--a mixed method study with an ecological restorative approach. Rev Lat Am Enfermagem. 2013;21:146-54. doi: 10.1590/S0104-11692013000700019

35. Letvak SA, Ruhm CJ, Gupta SN. Nurses' presenteeism and its effects on self-reported quality of care and costs. Am J Nurs 2012;112:30-8; quiz 48, 39. doi: 10.1097/01. NAJ.0000411176.15696.f9

36. Kessler RC, Ames M, Hymel PA, Loeppke R, McKenas DK, Richling D, Stang PE, Ustun TB. Using the WHO Health and Work Performance Questionnaire (HPQ) to evaluate the indirect workplace costs of illness. J Occup Environ Med 2004;46(Suppl 6):S23-37. doi: 10.1097/01. jom.0000126683.75201.c5

37. Kessler RC, Barber C, Beck A, Berglund P, Cleary PD, McKenas D, Pronk N, Simon G, Stang P, Ustun TB, Wang P. The World Health Organization Health and Work Performance Questionnaire (HPQ). J Occup Environ Med 2003;45:156-74. PMID: 12625231

38. Kessler RC, Petukhova M, McInnes K, Ustün TB. Content and Scoring Rules for the WHO HPQ Absenteeism and Presenteeism Questions. Boston (MA): Harvard Medical School; 2007.

39. Bodur S, Filiz E. Validity and reliability of Turkish version of "Hospital Survey on Patient Safety Culture" and perception of patient safety in public hospitals in Turkey. BMC Health Serv Res 2010;10:28. doi: 10.1186/1472-6963-10-2

40. Johns G. How often were you absent? A review of the use of self-reported absence data. J Appl Psych 1994;79:574-91. doi: 10.1037/0021-9010.79.4.574

41. Johns G. Presenteeism in the workplace: A review and research agenda. J Organiz Behav 2010;31:519-42. doi: 10.1002/job.630

\section{Kultura bolesničke sigurnosti utječe na prezentizam i apsentizam: presječno ispitivanje u hrvatskih zdravstvenih djelatnika}

Zdravstveni djelatnici imaju visoku stopu ozljeda na radu i bolesti vezanih uz rad. Njihova odsutnost s posla zbog bolesti (apsentizam), kao i prisutnost na poslu kad su bolesni (prezentizam), mogu ugroziti bolesnikovu sigurnost i kvalitetu pružene zdravstvene skrbi. Slijedeći tu pretpostavku, htjeli smo utvrditi jesu li, i kako, prezentizam i apsenzitam povezani s kulturom bolesničke sigurnosti. Naš je uzorak obuhvatio 595 zdravstvenih djelatnika (150 liječnika i 445 medicinskih sestara) koji su odgovorili na upitnik Svjetske zdravstvene organizacije za mjerenje zdravlja i radne učinkovitosti te Upitnik o kulturi bolesničke sigurnosti u bolnici. Rezultati su potvrdili povezanost prezentizma i apsentizma s nekoliko dimenzija kulture bolesničke sigurnosti, ali ne i pretpostavku od koje smo započeli istraživanje. Suprotno našim očekivanjima, niži radni učinak (kao mjera prezentizma) bio je povezan s višom - a ne nižom - kulturom bolesničke sigurnosti. Apsentizam je bio povezan s nižom kulturom, kao što smo i očekivali. Ovi rezultati upućuju na to da kultura bolesničke sigurnosti utječe na ponašanje zdravstvenih djelatnika, odnosno na njihov prezentizam i apsentizam, a ne obrnuto. Visoka kultura bolesničke sigurnosti dovodi do prezentizma, a niska do apsentizma. Također vjerujemo da se upitnici o prezentizmu trebaju specifično prilagoditi zdravstvenoj skrbi kako bi se kvantitativnim i kvalitativnim metodama preciznije utvrdio niži radni učinak. 